\title{
Chinese Language Press in Austria: Discussing the 2008 Tibetan Unrest in Transnational Spaces
}

\author{
Carsten Schäfer
}

\begin{abstract}
This paper examines overseas Chinese identity construction in Austria by focusing on Europe Weekly, the biggest Chinese language newspaper in Vienna. The study adopts a quantitative and qualitative content analysis, with the latter focusing on Europe Weekly's reporting of the 2008 Tibet unrest and a comparison of the newspaper's coverage of the event to the media portrayals in the Austrian daily Die Presse and the Chinese People's Daily. Findings show that the Weekly in general promotes a pluralistic view for its readers and, thus, provides a narrative of a hybrid Chinese identity that encompasses Austria, China, the local Chinese community in Austria, as well as transnational spaces of the Chinese diaspora. Yet, while the Weekly normally promotes plurilocal attachments and flexible self-assurances of the Chinese in Austria, the study also reveals how the process of Chinese immigrant identity formation might change when the country of residence and the home country find themselves in antagonistic positions. The findings demonstrate both the difficulties of maintaining transnational attitudes in times of a crisis and strategies of Chinese immigrants to somehow remain open towards the host society while simultaneously promoting the rhetoric of solidarity with the Chinese nation state.
\end{abstract}

Keywords: Chinese immigrants in Austria, Overseas Chinese, Overseas Chinese policy, cultural identity, transnationalism, ethnic media, third spaces, 2008 Tibet unrest

Schäfer, Carsten. "Chinese Language Press in Austria: Discussing the 2008 Tibetan Unrest in Transnational Spaces." In Vienna Journal of East Asian Studies, Volume 8, eds. Rudiger Frank, Ina Hein, Lukas Pokorny, and Agnes Schick-Chen. Vienna: Praesens Verlag, 2016, pp. 163-191. https://doi.org/10.2478/vjeas-2016-0006 


\section{Introduction: The Chinese in Austria}

The history of the Chinese in Austria is rather short. ${ }^{1}$ Numbers of Chinese immigrants started to rise only after the beginning of China's reform and opening policy in 1978, numbering from about 800 in the beginning of the 1980s to approximately 35,000 persons today. Nevertheless, there is some uncertainty about the exact numbers of people of Chinese descent living in Austria, since in official statistics only those with Chinese citizenship are taken into account. Beyond those statistically confirmed 15,000 Chinese passport holders, it is impossible to provide any exact data for the second and third immigrant generation, the naturalised citizens, or the illegal immigrants, all of whom are included into the notion of 'overseas Chinese."

The Chinese Diaspora in Austria is by no means a homogeneous group; it can be differentiated according to origin, occupation, social status, dialect, or time of arrival, to name only a few potential categories. However, in the eyes of Austrian people, Chinese immigrants are usually regarded as a single, coherent community. Austrian media convey the image of Chinese immigrants as a hard-working, business-minded, frugal but nevertheless exotic group of people, or as members of the Chinese mafia and human trafficking gangs (Schäfer 2014). In both cases, the media are implying the existence of a Chinese parallel society which is beyond reach for members of the mainstream society. It is against this background of an oversimplifying (and often obscure and even criminalising) image of the Chinese in Austria that I attempt to describe, as well as define what it means to be 'Chinese' in this country. In other words, this article examines overseas Chinese identity in Austria departing from the following questions: How do overseas Chinese manage and articulate their identities after arriving in Austria? Do they maintain their Chinese identity and function as the 'fifth column' of the rising People's Republic, as frequently implied by Western media (e.g. Manager Magazin, 3 April 2012)? Do they assimilate and become Austrian? Or do Chinese immigrants create something new, something hybrid which is neither Austrian nor Chinese-but overseas or Austrian Chinese?

These questions are addressed by analysing the Chinese language weekly $\bar{O} u$ zhōu Liánhé Zhōubào Àodili 欧洲联合周报奥地利 (hereafter: Europe Weekly), the most influential newspaper among Chinese immigrants in Austria. Media provides us with insight into the condition of immigrant communities, since they serve as source of information and communication tool for community members (Oswald 2007). It is to be understood as an important part of the Austrian Chinese Lebenswelt. Media influence the community's closeness to or distance from Austria as well

1 For an overview, see Kwok 2008; Kaminski 2011; Schäfer and Mosleh 2014.

2 In the context of this paper the term overseas Chinese is based on an ethnic definition and refers to both Chinese citizens living abroad and to foreign passport holders of Chinese origin. 
as China and, therewith, takes part in the process of negotiating Austrian Chinese identity.

Prior to answering the research question of overseas Chinese identity in Austria, it is necessary to discuss three issues that will lay the ground to the analysis of Europe Weekly: First, how is the term identity understood in this article? How does a given group's identity come into being, develop, and change? Second, what points of reference or identity options have, in theory, an impact on overseas Chinese identity in Austria? Third, how does print media production and consumption influence the formation of identity? After discussing these theoretical issues of identity building, I will present the findings of the content analysis of Europe Weekly. The latter consisted of a quantitative and qualitative content analysis (Mayring 2000) of eight issues of the newspaper from 17 March to 5 May 2008, with the qualitative content analysis focusing on the Europe Weekly's reporting of the 2008 Tibet unrest. The overseas Chinese newspaper's coverage will be analysed and compared to the media portrayals in the Austrian daily Die Presse and in the mouthpiece of the Chinese Communist Party (CCP), the People's Daily (Rénmín Ribào 人民日报), in order to understand how overseas Chinese identity in Austria is managed during a time of crisis.

\section{Cultural Identity}

The word 'identity' has its root in the Latin noun identitas, which means 'the same'. Cultural identity refers to sameness according to customs, practices, values, and world views that define social communities such as those based on nationality, ethnicity, or race. Furthermore, it refers to a sense and imagination of who we are and where we belong to and, most importantly, how we relate to other groups. In other words, cultural identity is a group's self-definition vis-à-vis an environment that is perceived as different (Hall 2004; Sen 2007). In the following section I aim to answer how identity comes into being.

While identity was portrayed as something fixed and clearly defined for a long time, the exact opposite proves true according to more recent research. It is socially constructed, and this process of construction is, to put it simply, driven by two forces: Cultural identity is dependent on self-ascription - that is, the self-definition of a community of people - and ascription - that is, the definition by others. People define and construct their identity according to their own experiences and perceptions as well as in interaction with and in relation to neighbouring groups. To be more precise, cultural identity is, above all, constructed through difference (Hall 2004). Identity cannot simply rely on self-reference, but depends on a group's imagination of being different from its environment or other groups at a given time and place. Such differences find their expressions in language, moral values, habits, 
customs, and all the other areas of the Lebenswelt. Since the environment changes over time, the notion of the self changes too.

A group's ability to select and exclude in its own right what it perceives as the 'self' and the 'other' is a fundamental aspect for the formation of identity. Nevertheless, identities are not simply a matter of in-group choice, since resources for identity formation also derive from a group's specific socio-cultural context (Cornell and Hartmann 2010; Phinney and Ong 2007). Thus, it is also the surrounding sociocultural environment, or the 'constitutive outside' (Hall 2004: 17), that has an impact on a group's self-definition. The environment provides the stimulus for a group's identity transformation: When environments change, the consequence is a necessity to redefine oneself in the presence of altered circumstances. What was deemed a valid element of identity formation in one situation can be questioned or eradicated in the next - as in the case of immigration. Former ascriptions can lose their validity and thus be altered, enriched, or changed completely in the course of time. In this sense, identity is, freely adopted from Harrell, a group's 'conscious selection of some of the available evidence' (Harrell 1995: 5) provided by the group's environment.

The process of in-group selection is highly competitive (Gergen and Gergen 2009). Different members of a community have different ideas of how to describe their own group. Identity requires a consensus about the perception of what is true, correct, and good - in other words, it requires a master narrative about the group's self that is accepted by the members of this group. The process of selecting and reselecting includes all members of the given group, who negotiate and try to come to terms with the question about their 'self'. As a consequence, there is no single way of imagining what it is to be overseas Chinese in Austria. To the contrary, both different people and groups have different understandings of this term, each of them competing with each other about the 'true' meaning of 'Chineseness abroad'. Nevertheless, any individual identity is articulated and portrayed by its holder as fixed within clearly defined borders.

To sum up, the definition of identity in this article follows constructionist theories (Berger and Luckmann 2009) and not essentialist principles. Identities are presumed to be socially constructed, relational, contextual, and fluid. It is understood that identity is the result of an interplay between an external environment that influences a group's perception of itself, and a community's in-group selection visà-vis this environment. Thus, interactions both within the Chinese community and between members of the Chinese community and outside groups constitute overseas Chinese identity.

This perspective, on the one hand, implies a focus on the institutions established by overseas Chinese in Austria that allow for in-group communication and interaction and, thereby, provide platforms for negotiating identity. It is widely assumed that overseas Chinese identity formation mainly relies on the following three institu- 
tions: associations, media, and language schools (Sun 2006). Research on these socalled 'three pillars' of overseas Chinese communities therefore can be seen as a viable approach to questions of Austrian Chinese self-perception. On the other hand, the above theory of identity formation asks for an examination of the socio-cultural environment that influences the identity construction of overseas Chinese in Austria. If identity has to be understood as embedded within a set of different influencing factors, we have to ask what environmental socio-cultural 'others' are exerting their influence or even try to impose a homogenised identity on overseas Chinese in Austria.

In the following, I will explore four ideal-typical socio-cultural spaces expected to contribute to identity formation, including the place of residence (or host country), the place of origin (or home country), the local Chinese community in Austria, as well as the transnational Chinese diaspora. Each and every of the four sociocultural spaces are potential points of reference that may simultaneously influence the formation of Chinese identity in Austria by offering spaces for identification.

\section{Identity Options}

In this section, the elements of the 'constitutive outside' of overseas Chinese will be investigated and compared, namely Austria, China, and local as well as transnational overseas Chinese communities. I will examine each of these four potential points of reference that influence the formation of overseas Chinese identity in Austria, before turning to a discussion of the impact of on immigrant community's identity construction in the following section.

\section{Place of Residence: Austria}

One important factor that influences the construction of overseas Chinese identity is the place of residence. Two aspects are crucial in defining an immigrant group's ability to integrate or even assimilate into a host society and to identify with its values and habits, namely the degree of openness of the host country towards immigrants and the willingness and capability of immigrants to adjust to the new environment. If both requirements are met, identification with the host society may lead to assimilation, which implies a complete absorption of immigrants into the host society. Some authors, such as Wang Gungwu (1991: 136), take the-obviously controversial - view that '[f]or most Chinese abroad, it is the non Chinese environment that impinges on their lives most directly.' While it is true that assimilation is by no means the only option for immigrant groups in a foreign country (as was long held in social sciences), Wang reminds us that it should still be regarded as one 
potential outcome of the immigration process. In fact, in research on immigration since the late 1990s, we can observe a 'revived interest in assimilation' (Morawska 2004: 1372; Brubaker 2010; Hsu and Serri 1998).

Despite the fact that the second Austrian Report on Migration and Integration (Österreichischer Integrations- und Migrationsbericht; Faßmann 2007) criticises the overall state of immigrants' integration in Austria, a closer look into the conditions and structures of the Chinese community in Austria and its members' interactions with non-Chinese Austrian society allows for a distinctly more positive picture. Efforts both on the part of the Austrian state and society as well as by overseas Chinese individuals and organisations for promoting integration of Chinese migrants in Austria should not be overlooked. Actors on both sides provide information and services aiming at fostering integration, such as German language courses, legal advice, informative meetings for restaurateurs, or leisure activities and projects of civic education to name a few. Austrian institutions like the MA $17,{ }^{3}$ the Chamber of Commerce, or the Integrationsfonds ${ }^{4}$ keep close relations with organisations and individuals of the Chinese community. At the same time, overseas Chinese associations and language media frequently stress the need for the Chinese to 'enter the mainstream society' and convey the image of Austrian Chinese as a well integrated and respected group. Both Austrian and overseas Chinese institutions constitute opportunity structures that are likely to increase the overseas Chinese willingness to identify with Austria. Furthermore, Austrian politicians use immigrant media to convey the narrative of Vienna as a multicultural place and of Chinese immigrants as an integral part of the cultural attractiveness and economic success of the Austrian cities (Schäfer 2014). There are no Chinatowns in the sense of residential segregation neither in Vienna nor in other Austrian cities. Instead, Chinese are scattered throughout the cities, therefore being in contact with local neighbors (Mosleh 2012). Overall, albeit the somewhat problematic integration policy as described in the Report on Migration and Integration, Austria can be regarded as a potentially important point of reference for a positive identification.

\section{Place of Origin: China}

Since the beginning of the Reform and Opening policy, China seeks to (re-)establish a tight relationship with the overseas Chinese, since at least parts of them promise

3 The Municipal Department 17 focuses on migration, integration, and diversity. Its work includes research and reports on questions regarding these topics. https://www.wien.gv.at/menschen/integration/, accessed 3 February 2016.

4 The Austrian Integration Fund in Vienna is an organisation that aims at fostering business, cultural, and social integration of immigrants in Austria. http://www.integrationsfonds.at/wien/, accessed 3 February 2016. 
enormous financial, intellectual, and political resources for China's modernisation. China takes measures to both strengthen the emotional ties of the overseas Chinese with the homeland and to integrate them into nation state structures (Weggel 1999; Thuno 2001; Barabantseva 2005).

The term 'overseas Chinese' (huáqiáo huárén 华侨华人), as understood in the PRC, includes both Chinese passport holders and ethnic Chinese with foreign citizenship. Overseas Chinese are regarded as part of the 'big Chinese family' grouped around the Chinese Communist Party. According to this notion of belonging, they are bound to China by ties of blood, descent, and culture, as well as by sharing the state's modernising goal (Nyiri 2002). Thus, there is a deep-rooted assumption that overseas Chinese belong to China and not to their country of residence. As such, overseas Chinese affairs have come to be regarded as a matter of national interest.

In accordance with the PRC's official overseas Chinese discourse, between 1977 and the mid-1980s, a number of political bodies were created (or re-created, after they were suppressed during the Cultural Revolution) for dealing with overseas Chinese matters. The implementation of China's overseas Chinese policy is basically in the hands of the Overseas Chinese Affairs Office (OCAO), re-established in 1978, and the local Chinese Embassies. Beside these key actors, a number of official and semi-official policy agencies are involved in overseas Chinese politics. The objective of this apparatus of overseas Chinese affairs is to establish direct links with the overseas Chinese all over the world and to guarantee the Chinese state's closeness to them. China sends out OCAO delegations to meet with overseas Chinese around the world and invites overseas Chinese to visit the country in order to bolster the ties with them. Furthermore, the PRC compiles and provides teaching materials for local Chinese schools and offers training to local teachers. At the same time, Chinese national media foster the cooperation with overseas Chinese newspapers and websites (Barabantseva 2005). Chinese embassies and other institutions encourage and assist the establishment of overseas Chinese associations and organise conferences and workshops about 'hot' topics, such as Tibet or the Senkaku/ Diaoyu Islands. As a result of such political measures, around 25 out of 55 overseas Chinese organisations in Austria are - in one or the other way-linked to organisations of the Chinese state. Thus, dealing with PRC authorities has become the norm for a large number of overseas Chinese individuals and organisations (Schäfer forthcoming). China uses these channels to undertake extensive propaganda in order to claim the identity of overseas Chinese.

This short outline of China's overseas Chinese policy illustrates the PRC's ability and intention to exercise influence over overseas Chinese identities. Against this background, Elena Barabantseva (2005: 14) writes about a 'de-territorialised ideology of nationalism'. From the perspective of the PRC, overseas Chinese in Austria are regarded as citizens of a de-territorialised Chinese state. Hence, the PRC be- 
comes a second important factor that potentially influences overseas Chinese identity construction in Austria.

\section{Third Spaces}

Migration studies have been focusing for a long time on processes of assimilation or marginalisation exclusively as the two contradicting elements of the migration process due to strong bonds with the place of origin. Tang Lu (2004: 5) has criticised this "false opposition of [homeland] "nationalism" and "assimilation" as a misleading concept that mistakenly implies that these two points of reference are the only available choices for overseas Chinese in forming their identities. Inspired by Tang $\mathrm{Lu}$ and others, I would like to add two further social spaces as potential factors shaping Chinese identity in Austria: local Chinese communities and transnational Chinese communities, both being manifestations of overseas Chinese hybrid or third culture identities.

The term 'third culture' (or third space) derives from Homi Bhabha's groundbreaking book The Location of Culture (1994). It refers to a social space where the cultures of the host country and the country of origin clash and fuse. Both Chinese local and transnational communities can be considered third spaces, intermixing aspects of both the home and the host society and thereby creating something new. However, as understood in the context of this article, they differ from each other in terms of the openness towards the host and home country. The local third space is understood - freely adopted from the original concept — as a form of hybridity that is not compatible with either the home or the host country but leads to ghettoisation as well as marginalisation from both places. In contrast to this, the transnational space is shaped by a hybridity that embraces the home and the host country as well as potentially other countries. It refers to immigrant's life horizons that are shaped simultaneously by the countries of origin and residence, and that can be influenced by co-ethnics in third countries.

\section{Local Third Space}

Whether overseas Chinese integrate into the mainstream society or not 'depends in part on the number of Chinese in each country' (Wang 1991: 146). In other words, the bigger the Chinese community, the bigger the chance to live a life strongly confined to this community. Empirical data show that many immigrants are encapsulated in their ethnic community, voluntarily or not (Morawaska 2004), as they often do not have the skills and abilities or the necessity and the wish to adapt to the mainstream society. At the same time, immigrants who left their home country years ago may find out that they have lost the sense of what is going on in their home 
country and that their knowledge about it is increasingly outdated. This holds true especially for transitional societies like China, which has undergone rapid social and cultural change since the beginning of Reform and Opening (Chen 2006).

Even if some authors take the view that certain social structures of ethnic communities foster the integration into the mainstream society (for example, Kissau 2008), this is not necessarily true in all cases. Instead, a strong orientation towards the ethnic community might become a permanent condition. In this case, ethnic communities function as a mobility trap that further estranges an immigrant from the host and the home country, a phenomenon that is called intra-group assimilation (Esser 1986; Treibel 1990). An important factor that influences intra-group assimilation is the so-called 'institutional completeness' of the ethnic community:

The presence of formal organizations in the ethnic community sets out forces that have the effect of keeping the social relations of the immigrants within its boundaries. It tends to minimize out-group contacts... The communities showing the highest degree of institutional completeness have a much greater proportion of their members with most of their personal relations within the ethnic group (Breton 1964: 196).

The degree of institutional completeness of the local Chinese community in Austria is reflected in the following numbers: Chinese in Austria have founded more than 55 associations, two newspapers, two websites, one TV program, and six schools. Although some of these institutions are aiming at enhancing integration in Austria or at nationalism towards the People's Republic, rather than reinforcing intra-group assimilation, the numbers still remain impressive and point to a high potential of organising oneself within the immigrant society. Beyond these organisations, the ethnic economy contributes to the institutional completeness of the local Chinese community. 2,000 Chinese restaurants, 50 Asia shops, and a comprehensive service sector provide multiple possibilities for economic integration into the Chinese community, especially in Vienna (see the Telephonebook for Chinese in Austria, 2012). All basic human requirements - such as finding friends, earning money, solving everyday life problems - can be met within the highly organised and institutionalised ethnic community. Thus, Chinese immigrants in Vienna could easily lead a life that is strictly confined to their own community without coming in contact with non-Chinese in Austria - and with people back in China. The local Chinese community in Austria (and especially in Vienna), therefore, can be regarded as a third important factor to the formation of the cultural identity of overseas Chinese.

\section{Transnational Third Space}

Transnationalism refers to a social phenomenon of increasing interactions between people across national borders. The term was first used in the 1980s and has long 
since become the leading theme in migration studies. Although there are somewhat different definitions of the meaning of transnationalism, the original definition of Basch, Glick-Schiller, and Blanc remains the most common one. They state that transnationalism is understood as 'the process by which immigrants forge and sustain multi-stranded social relations that link together their societies of origin and settlement' (Basch et al. 1994: 7)—and, in addition to this, often societies in third countries. On the basis of Basch's et al. pioneering study, many authors claim that today's immigrants are much less willing to embrace just one national culture compared to past generations. Instead, they are so immersed in the cultures of different countries, that they belong to no one but cultivate national loyalties and allegiance to multiple locations. As a consequence, they create multiple and hybrid identities that 'mix and match' elements of different cultures and are less anchored in one specific territory (Pries 2008).

In accordance with this trend in migration studies, many authors claim that transnationalism has given rise to new forms of lifestyles and consciousness of overseas Chinese (Nonini and Ong 1997; Pieke et al. 2004; Nyiri 2002 and 2007). Overseas Chinese transnationalism can be observed on both individual and organisational levels. Not only overseas Chinese individuals in privileged positions but also nonelite immigrants are increasingly able and willing to move in geographically complex social spaces. Many Chinese immigrants have ties with relatives and friends not only back in China, but also in different European countries. Through such networks, immigrants are simultaneously informed about opportunity structures in different places, always ready to move, thereby converting geographically dispersed localities into a single social space. As a consequence, transnational Chinese loyalties become attached to different social spaces, transcending any classic 'either-or' patterns.

Since the 1990s, we can observe that Chinese immigrants in Europe do organise themselves at a transnational level (Li 1999). Some associations are scattered all over Europe, whereas others are limited to only a few European countries. These new forms of community organisation facilitate social, cultural, political, and business ties among overseas Chinese in different places, often including China and several host countries. In Austria, too, some overseas Chinese organisations operate mainly on the transnational level. The Austria-China Council for the Promotion of International Trade, for example, aims to promote economic and cultural relations between Austria and China as well as other countries, while the Überseechinesenkomitee (Overseas Chinese Committee) is aiming at promoting the mutual understanding and friendship among Austrian and Chinese peoples. Both associations include overseas Chinese, Chinese, and non-Chinese members (Schäfer forthcoming).

The internet plays an important role in the development of transnational networks. It can criss-cross and transcend national boundaries without physical movement, and enables users to simultaneously take part in the life of both the host and 
the home countries - even in third countries as well. The internet fosters stronger and richer connections with like-minded people elsewhere and makes it easy to bring these dispersed groups together (Ding 2007). To conclude, in many fields of Chinese immigrants' everyday life we can observe the transnationalisation of social practices, and even identities, through sustained cross-border involvement on the individual, organisational, and media level.

To sum up, overseas Chinese in Austria are exposed to identity options that emanate from four different ideal-typical social spaces, namely Austria, China, as well as local and transnational third spaces. Combined, the four social spaces constitute a framework within which the meaning/s of overseas Chineseness is/are constructed and contested. Chinese in Austria may simultaneously establish affiliations with one, two, three, or four spaces as discussed above.

\section{Media and Identity Construction}

As narratives play a central role in the construction of identities, overseas Chinese media is one of the instruments that are involved in the contested process of identity construction (Shi 2010). If departing from the established views that to tell stories is a way of making sense of life (Bruner 2003), and that identities refer to 'the story we tell of ourselves and which is also the story others tell of us' (Sarup 1994: 95), it becomes evident that today's search for identity and belonging is closely intertwined with media production, that is the creation, circulation, and implementation of media narratives. As discussed above, identities are negotiated among members of a given group and require master narratives that provide a consensus about a group's selfperception. Media are able to impose hegemonic models of identity by creating such master narratives. Since media consumption is '[o]ne everyday practice of being Chinese' (Sun 2006: 2), the media allow the individual reader to 'educate' him or herself in Chineseness (Wickberg 2007) and helps the group to 'form its own distinctive cultural identity' (Tang 2004: 6). Chinese media distributed in Austria, therefore, offer certain versions of Chineseness to the members of the community.

Europe Weekly, the oldest Chinese language newspaper in Austria, was first launched in 1991 and has developed steadily ever since. Today, it claims a circulation of 5,000 copies, which makes it the highest-circulation Chinese language newspaper in Austria. It mainly targets the local Chinese speaking community, but also reaches out to Chinese in eastern European neighbouring states as well as to mainland China. It can be purchased in Asia-supermarkets in Austria and can be read cost free in most China restaurants in the country. Europe Weekly can be seen as a tool to participate in the struggle of defining the identity of Chinese immigrants in Austria. It selects and perpetuates certain images, information, and narratives available within the model set out above while, at the same time, leaving out others in order to 
create a unified picture of the meaning of being Chinese in Austria. Europe Weekly thereby helps to give its readers meaning to an otherwise complex world. Its narrative positions overseas Chinese in specific parts within the aforementioned social spaces. When ascribing certain attributes to the overseas Chinese in Austria, the media are trying to essentialise and hegemonise Chineseness. In this sense, media narratives are instrumental, as they are representing and thus promoting certain overseas Chinese role models and identities to their readers as the only available means of identification. Chinese language media in Austria serve as a platform, where Chinese immigrants can unfold their own identity narratives by selecting from the references provided by the Austrian, Chinese, local, and transnational overseas Chinese regimes of truth. Consequently, immigrant media coverage offers us the opportunity to study and understand overseas Chinese identities in Austria. It gives us the impression of a group's self-perception as well as its perception of the environment (Oswald 2007). It is one of the available barometers for the formation and management of overseas Chinese identity in Austria.

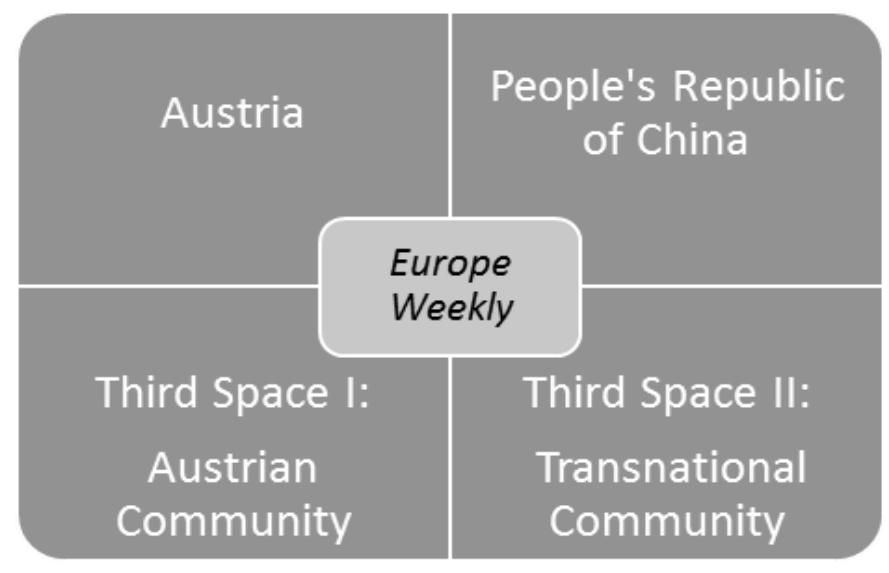

Source: Schäfer forthcoming

Austrian overseas Chinese are caught up at the intersection of multiple, sometimes conflicting social spaces. The rectangle model above represents the set of impact factors potentially influencing overseas Chinese identity formation. Departing from the assumption that 'being Chinese is what you make of it' (Christiansen 2003: 173), the model is used as the theoretical foundation for the analysis of identity construction in the overseas Chinese Europe Weekly. 


\section{Analysis and Findings}

In this section I will discuss the public representations of overseas Chinese identity in the Europe Weekly. The analysis of Europe Weekly will be presented in three parts. The first part will provide an overview of the organisation structure, the purposes, and the policies of the editor in chief and the (re-)sources of the Weekly's content. The second part will draw an outline of the content composition and, finally, in the third part, I will concentrate on the qualitative content analysis of the depiction of the 2008 Tibet crisis and the comparison of Europe Weekly's coverage with the reporting of the Die Presse and the People's Daily.

\section{Organisational Structure and Content Sources}

While Europe Weekly was originally founded by Chinese immigrants in Vienna, in 2006 it became integrated into the so-called Ōuzhōu Liánhé Zhōubào, a transnational organisation of Chinese language newspapers in Europe that is closely affiliated with the mainland Chinese Xīnmín Wănbào 新民晚报, a state controlled daily. The project was initiated by one of the oldest overseas Chinese newspapers, the $\bar{O} u z h \bar{o} u$ Shíbào 欧洲时报, located in Paris, and the Xīnmín Wănbào in Shànghăi 上海. These two newspapers cooperate to produce a pool of print-ready newspaper pages that are at free disposal to all cooperation partners. Between 2006 and 2011, nine small Chinese language weeklies in different European countries, including the Austrian Europe Weekly, joined the project, since it promised an improvement in editorial professionalism and layout as well as a diversification and increase of the content (Wáng 2007). ${ }^{5}$

As a consequence, one half of the formerly autonomous Europe Weekly has been produced in the PRC as well as in Paris ever since. In this way, China is able to control Chinese language media content beyond its national territory. Nevertheless, the remaining 50 percent of the newspaper's content is still produced and written independently in Austria. This locally produced part of the newspaper can be subdivided into three content categories: first, news and stories about the Chinese in Austria, written by freelancers (one to four pages); second, advertisement, mostly of local ethnic businesses (ten or more pages); and third, news and information about Austria, most of which is translated from the Austrian dailies Kurier and Die Presse or the weekly News (one to two pages). Thus, the staff of Europe Weekly in Vienna do not only cooperate with the editorial offices in Paris and Shanghai, but also with those of Austrian media. Most importantly, within this locally produced part, the

5 http://www.hudong.com/wiki/ 欧洲联合周报, accessed 22 July 2010. Interview with Wáng Găn 王敢, 31 March 2010, Vienna. 
newspaper is able and willing to take up a critical stance towards China, even though sometimes only 'in a roundabout way', as the editor in chief stated in an interview. ${ }^{6}$

According to the editor in chief, the main purpose of the newspaper includes three elements. First, to enhance the integration of overseas Chinese in Austria; second, to safeguard their rights, interests, and security in Austria; and third, to maintain links to China and support China's national interests. What seems to be contradictory, at first sight, is in fact the manifestation of the transnational objective of the editorial desk in Vienna. The orientation towards both Austria and China is regarded as two sides of the same coin. Moreover, it is interesting to note that overseas Chinese are mentioned separately, implying that sometimes overseas Chinese interests do not automatically coincide with those of Austrian and/or Chinese citizens.

To conclude, Europe Weekly can be understood as an ideal-typical transnational organisation. The local autonomy of the editorial office in Vienna allows for an adaptation to the specific needs and interests of the Austrian Chinese community. While the participation in the Liánhé Zhôubào project enables it to profit from otherwise unavailable resources, it also makes the Weekly dependent on media outside the Chinese community in Austria. The content is drawn from Paris and Shanghai, from Austrian newspapers, and from in-house production in Vienna. This diversity of sources is an expression of the newspaper's objective. By simultaneously serving integration, Chinese nationalism, intra-group assimilation, and transnational attitudes, the newspaper aims to create a 'diasporic public sphere' (Appadurai 1996: 21) that links its readers to Austria, China, and the Chinese community in Austria, as well as in other countries. The organisational structure, the content resources, and the Weekly's mission statements indicate orientations towards and attachments to multiple localities, providing overseas Chinese in Austria with multifaceted points of reference to perform their overseas Chinese identity according to different expectations and requirements.

\section{Quantitative Content Analysis}

Europe Weekly consists of 36 pages in total, with approximately 15 of them being in-house productions and about 20 obtained from the shared text-pool. Of the four main sections, the one related to China and the overseas Chinese outside of Austria mostly derives from the Liánhé Zhōubào pool, whereas the rubrics about the Chinese in Austria and the Austrian mainstream society are produced locally.

On the first one or two pages, readers usually find news and information about Austria, especially Vienna. By providing all kinds of information, for example about

6 Interview with Wáng Găn, 31 March 2010, Vienna. 
cultural and social events in Vienna and other cities, Austrian news and history, or legislation and the political system in Austria, the Europe Weekly functions as a socialisation agent for overseas Chinese, potentially preparing them a way towards mainstream society. In these sections, Europe Weekly addresses its readers as members of the Austrian mainstream society or, at least, provides basic knowledge of the latter and its cultural values. It fosters the construction of an overseas Chinese identity that is compatible with the situation in Austria.

A large block of the newspaper, usually about eight to ten pages, is devoted to China. This part covers multifaceted topics, such as Chinese sports, television and film, eating and drinking, literature, business news, or news about Fujian and Zhejiang, the native places of most Chinese in Austria. Most of these articles are produced in Paris and Shanghai. This part of Europe Weekly helps its readers to keep in touch with their former home or the home of their (grand-)parents and treats them as members of the Chinese motherland.

Another large block-approximately 15 pages - focuses on the Chinese community in Austria. It contains news about activities of Austrian Chinese individuals, associations, schools, and media, as well as a large number of advertisements, mainly by Chinese businesses in Vienna. This part of the Weekly is exclusively produced by the staff in Vienna. In these sections, the newspaper implies that overseas Chinese are part of the local Chinese community. It not only helps Chinese immigrants to organise their life beyond the mainstream society by offering practical help, jobs, or housing, but it also provides a platform to express specific local immigration and life experiences, opinions, feelings and needs, thus ascertaining a common sense of belonging among Austrian Chinese.

Finally, a small section of Europe Weekly provides news about overseas Chinese around the world. The stories in this part cover a wide range of topics, including large scale transnational meetings or traditional holiday activities. These articles derive from the shared text pool. They create the image of a global Chinese diaspora, thus integrating Austrian Chinese readers into the global Chinese family scattered around the world, and allowing readers to imagine themselves as part of a transnational Chinese community. Moreover, the paper has sections about lifestyle and health care that are not classifiable as part of one of the above mentioned sections. The front page, which is also produced in Vienna, cannot be exclusively ascribed to one of the four spheres of reference or spaces of identification. Instead, cover stories about Austria, China, or the Chinese in Austria alternate week by week, thus emphasising the transnational orientation of the Weekly.

The content that is produced in China and France tends towards the formation of a transnational or national Chinese identity, thus helping Chinese immigrants 'to escape from the territorial and jurisdictional confines of the countries where they live' (Verhulst 1999: 33). However, since Europe Weekly at the same time enjoys a great deal of independence, this orientation does not isolate the readers from their 
immediate environment, but also makes a contribution to the integration of readers into the Austrian Chinese community and the Austrian mainstream society. To this effect, Europe Weekly contributes to a pluralistic mindset of its readers by conveying the images of Austria, China, the Chinese community in Austria, and the communities in other countries as integral and coexistent parts of their everyday world. In accordance with the findings of the previous chapter, we can conclude that the Weekly aims to promote pluri-local attachments and flexible self-assurances of the Chinese in Austria. The newspaper provides information that can be utilised by its readers to context-dependently perform different versions of Chineseness that comply with all four spaces of reference and the expectations of their respective members. In other words, the Weekly's content is tailored to the diverse needs of Chinese immigrants in Austria: Success and satisfaction of needs should be guaranteed in Austrian, Chinese, and third space contexts respectively. Europe Weekly provides its readers with the raw material to make it possible.

While this model of multi-dimensional identity formation has been described as being based on the harmonious coexistence of the different social and cultural worlds so far, in the following section it will be tested in other circumstances putting the frictionless build-up of the rectangle at stake.

\section{Qualitative Content Analysis}

In this section, I focus on the Weekly's reports in times of a crisis, that is to say, when the West (Austria) and China find themselves in antagonistic positions. This was the case during the 2008 Tibet unrest, a series of Tibetan demonstrations and riots against Han Chinese predominance that started from Lhasa and soon spread to other Tibetan areas in the provinces of Gānsù 甘肃, Qīnghăi 青海, and Sìchuān 四川. The media, both in China and Austria, reported extensively on that event in March and April of 2008, yet relying on and providing strongly contrasting portrayals and commentaries on what happened and why. Western media, including those in Austria, mainly sympathised with the Tibetans and their claims and criticised or even condemned China's violent crackdown of the unrest and violations of human rights. In contrast, Chinese media accused the West that there was a strong bias in their media coverage, including deliberate inaccurate presentation and distribution of false information about the event. China's media further accused the Dalai Lama and the so-called 'anti-Chinese international forces' (guójì fănhuá shili 国际反华势力) of orchestrating the protests (People's Daily, 21 March 2008). Contrary to Austrian media reports, China focused exclusively on the narrative of riots caused by Tibetans while simultaneously denying the existence of any peaceful demonstration, and claiming that authorities had dealt with the situation according to law. 
The covering of the riots in Tibet in March 2008 provides us with the opportunity to analyse Europe Weekly's handling of a situation, in which different components of the pluri-local world promoted and created by the Weekly are suddenly in sharp contrast to each other. Against this background, the content of Europe Weekly's reporting on the Tibetan crisis will be analysed, partly by comparing it to the media coverage in the Austrian daily Die Presse and the mouthpiece of the CCP, the People's Daily. What position does the overseas Chinese weekly adopt in this situation, and does it show any inclination towards the Austrian or the Chinese narratives? Or, on the contrary, adheres to a 'third culture' position? How, then, is overseas Chinese identity in Austria managed and conceptualised during a time of crisis?

Even though Europe Weekly took a rather neutral stance in the first week, from the second one onwards the newspaper started to adopt the official Chinese interpretation of the crisis and reproduced the narratives of the Chinese government, as can be seen in its treatment of the following five aspects:

1. The character of events: In line with the People's Daily, Europe Weekly soon began to speak about lawlessness, rather than a legitimate revolt as reported by Austrian media. The Weekly downplayed the incident to the criminal activities of a small number of villains, who were opposed by the majority of Tibetan people and the Chinese government. It accused the Dalai Lama of orchestrating the protests. Ignoring the statements of Austrian media, such as the Die Presse that accused the Chinese government of human rights violation (13 March 2008), Europe Weekly assured its readers that the few people involved in the protest would be dealt with in accordance with law (Europe Weekly, 17 March 2008: 1). Articles in the Weekly repeatedly quoted the Chinese ambassador in Vienna as a channel for propagandising official Chinese narratives (Europe Weekly, 24 March 2008: 1; Europe Weekly, 31 March 2008: 4). The voices of Austrian politicians were not heard in the coverage. Only one of the many articles about the riots criticised the Chinese government for its ignorant attitude towards the Tibetan people, the Dalai Lama, and the Western public opinion, thus deviating from the official Chinese narratives (Europe Weekly, 7 April 2008: 18).

2. Tibetan history: All three newspapers-Europe Weekly, People's Daily, and Die Presse - linked the March 2008 events with the Tibetan uprising of March 1959 (Die Presse, 14 March 2008; People's Daily, 6 April 2008). In the depiction of this historical event, Europe Weekly fully complied with China's official historiography. The 1959 Tibetan uprising was described as a revolt staged by the Tibetan upper class to oppose social reforms and to maintain serfdom. In order to secure the national unification and to liberate the Tibetan people, the Chinese government, according to Europe Weekly, suppressed the revolt of the reactionary group, thus 
paving the way to Tibet's successful economic and cultural construction in the following decades (Europe Weekly, 7 April 2008: 15).

3. The threat of boycotting the Olympics: Soon after the unrest had broken out, Die Presse (21 March 2008) and other Western media broached the subject of boycotting the upcoming Beijing Olympic Games. By way of contrast, Europe Weekly reported about protest rallies of overseas Chinese around the globe in order to support Běijīng's 北京 stance towards Tibet, criticise the Western media and politics for allegedly false accusations against China, and promote the Olympic Games. Europe Weekly clearly rejected the idea of a boycott and promoted the myth of a global Chinese family centered around Beijing (Europe Weekly, 31 March 2008: 1). While Die Presse created the image of China as an internationally isolated state and openly discussed a boycott of the Olympics, Europe Weekly reported about broad international (including Austrian) support for the upcoming Olympics in Beijing (Europe Weekly, 31 March 2008: 1).

4. The torch relay: The difference between Europe Weekly and the Austrian Die Presse also becomes quite evident in the reporting on the Olympic torch relay. Western media, among them Die Presse, reported about the torch relay in Paris and San Francisco being accompanied by protests by advocates of Tibetan independence and human rights groups (Die Presse, 7 April 2008). In Paris, these protests even forced the path of the torch relay to be shortened after the torch had been extinguished several times. In contrast to Western newspapers criticising China for its Tibet politics, Europe Weekly stuck to the official Chinese narratives. Instead of reporting about massive anti-Chinese protests in several European and American cities, it was writing about individual violent criminals. Protesters were condemned as disrupters and for violating the rights of those bearing the torch. In line with Chinese state media, the Austrian Chinese newspaper paid homage to the Chinese handicapped torch bearer Jin Jing, who was 'attacked' (xiji 袭击) by separatists during the torch relay in Paris (Europe Weekly, 28 April 2008: 4). In both Chinese and overseas Chinese media she was hailed as a national hero who defended the dignity of the Olympic torch (People's Daily, 9 April 2008). While completely ignoring protests against China's Tibet policy in Austria, the newspaper limited its visual angle to the pro-Beijing overseas Chinese demonstrations around the world, thus detaching Austrian Chinese from their local environment and incorporating them into the global pan-Chinese diaspora grouped under the banner of the Communist Party.

5. The role of the Western media: In accordance with China's state media (People's Daily, 24 March 2008), Europe Weekly condemned the alleged bias and dishonest reporting about the riots in Tibet by 'some' Western media. It attacked 
Western media for ignoring the truth and attempting to sabotage the upcoming Beijing Olympic Games by using 'excuses' (jiēkǒu 借口), such as democracy or human rights (Europe Weekly, 24 March 2008: 1; Europe Weekly, 31 March 2008: 4).

\section{Discussion}

The above short but exemplary overview of Europe Weekly's coverage of the 2008 Tibetan unrest shows that the newspaper, by and large, abandoned its transnational orientation when faced with a critical situation in China with repercussions on the country's relations to the outside world. As could be seen in the first two parts of the analysis, under normal circumstances, Europe Weekly would refer its readers to all four spaces of identification for reasons of orientation. Instead of creating differences and contradiction, it overall regards Austria, China, as well as the local and transnational Chinese communities as integral parts of the overseas Chinese Lebenswelt in Austria. However, as soon as elements of the overseas Chinese life horizon get caught in an antagonistic conflict, Europe Weekly seems to lose its openness towards these different sources of identification and replaces hybridity and pluri-locality by dichotomy and binarity. In this specific situation, there are only very few instances when Europe Weekly refrains from reproducing China's official media narratives - nevertheless, it is important to take note of some minor yet important variations that differentiate the overseas newspaper from its mainland Chinese counterparts.

In one issue, the newspaper published a number of critical comments selected from the internet, albeit not without indicating that the content published on that specific page does not represent the viewpoint of the Weekly's staff and editors. One of the postings made reservations regarding the pro-Chinese attitudes of his coethnics that might lead to a serious estrangement between Chinese immigrants and the Austrian mainstream society. Another posting criticised the 'blind spots' in Beijing's Tibet policy. Beijing was accused of ignorance towards the Dalai Lama and the interests of the Tibetan people. The author further advised the Chinese media to handle conflicts with the Western world in a more civilised way, instead of simply attacking and accusing the West (Europe Weekly, 28 April 2008: 6). Here, Europe Weekly gave its readers the opportunity to experience skepticism against certain policies of the Chinese government and listen to critical voices raised against anti-Western attitudes of fellow Chinese immigrants-while at the same time trying to minimise the risk to get itself into trouble.

Apart from such cautious presentation of minority voices, the Weekly largely ignored the viewpoints of Austrian media and reproduced the Chinese propaganda in its coverage of the Tibetan crisis. By conveying the PRC's official narratives, $\mathrm{Eu}$ - 
rope Weekly facilitated its readers to connect emotionally with China, thus fostering a pan-Chinese national identity among the 35,000 Chinese in Austria. The newspaper continuously reported overseas Chinese acts of solidarity around the world, creating the image of a single mainland oriented patriotic community. Instead of treating Austrian Chinese as a specific group of people in their own rights, they were just presented as part of a big pan-Chinese family. By attaching positive stereotypes to China and negative ones to the Western world, the reporting contributed to a dichotomisation of the overseas Chinese world. People and institutions in the West were accused as liars, violent criminals, and even imperialists. China and the Chinese on the other hand were represented as advocates of freedom and as victims of a Western conspiracy. The act of creating difference and identification of the 'Other,' which is important as a prerequisite for identity formation, becomes 'threatening, a site of danger, of negative feelings, of splitting, hostility and aggression towards the "Other" (Hall 2004: 238) at this point. As overseas Chinese were pushed towards a bipolar world, coined by a conflict between the good Chinese 'We' against the evil Western 'Other,' the third spaces were not part of or present in the coverage of the Tibet unrest anymore. The Tibet reporting of Europe Weekly only very rarely deviated from these stereotypes; for the most part, it intended to integrate Austrian Chinese into a deterritorialised Chinese nation state and detach them from their Western environment.

These findings beg the question why a newspaper with an overall transnational orientation, as in the specific situation described above, suddenly transformed into something close to a mouthpiece of the Chinese government. What could be the factors that led to the Weekly's closeness to mainland Chinese media narratives and the exclusion of Austrian voices despite a certain extend of autonomy and links to Austrian media counterparts? For a tentative answer to these questions, attention should be paid to two specific issues. First, China's self-ascription as a victim of the West seemed to be in line with the feelings and experiences of those Chinese immigrants that often experience discrimination by members of the mainstream society. As Liu (1998: 592) has argued, by drawing on James Clifford's work, 'diaspora consciousness is constituted by "the experience of discrimination and exclusion" and by "a shared and ongoing history of displacement, suffering, adoption, and resistance".' This is also true for parts of the Chinese immigrants in Austria (Schäfer forthcoming). The coinciding of reported and perceived Western discrimination becomes a powerful force for the solidarity between Chinese inside and outside China. Second, Chinese and Austrian media incorporated the overseas Chinese perspective to a very different degree. Mainland Chinese media provided space for overseas Chinese voices as long as they agreed with China's handling of the crisis, whereas the Austrian media mostly ignored the voices of Chinese immigrants in Austria. Instead, Austrian media took up a critical stance against China and therewith, even if indirectly and unwittingly, against all Chinese. Thus, it can be argued 
that, in this difficult situation, the overseas Chinese community found itself unable to assert its place in the Austrian mainstream discourse and society. To make it even worse, during the Tibetan crisis, Tibetans in Austria were repeatedly portrayed in articles in Die Presse, while the much bigger Chinese community was mentioned only once. Facing this situation of marginalisation in their country of residence, overseas Chinese were prone to turn to the People's Republic that was eager to provide platforms for expressing patriotic thoughts and feelings within its national media sphere and, thus, a space for positive identification. Chinese immigrants made use of the identity resources most readily offered by the Chinese side. The findings indicate that, under these circumstances, Europe Weekly's media representatives were willing to accept their role prescribed by China.

Nevertheless, this does not mean that the Weekly as a whole distanced itself from Austria. Even during the coverage of the Tibetan unrest in March and April 2008, it continued to provide learning material for the Austrian naturalisation test or to report on initiatives of Austrian-Chinese friendship, as in the case of an event organised by the Confucius Institute Vienna in cooperation with the Vienna Conservatory (Konservatorium Wien) (Europe Weekly, 21 April 2008: 4). In many cases, we find such pro-Austrian articles right next to the anti-Western ones about the Tibetan unrest, softening the patriotic stance of the pro-Chinese Tibet reporting. Furthermore, while the Europe Weekly did reproduce official Chinese narratives of Western intrusion on Chinese interests, it always shied away from applying them to Austria. On the one hand, Europe Weekly ostentatiously exhibited pan-Chinese nationalism by criticising 'the West' but, on the other hand, refused to include Austria in this notion of 'the West'. 'Austria', in contrast to the 'West', was never explicitly called a counterpart. This can be understood as a strategy to avoid criticism against the host country in order to prevent a direct conflict with the Austrian society and state. Thus, the door towards the Austrian mainstream society always remained open. Emotional attachment with the People's Republic was accompanied by a strive for integration in Austria and Austrian-Chinese friendship. By shying away from including Austria into its general anti-Western stance, the Weekly seemed to leave a 'loop hole' for an identification of its readers with their place of residence, thus displaying an attitude that can be described as transnational.

At the same time, Europe Weekly tried to meet the wishes of part of the overseas Chinese in Austria who wanted to read articles not exactly in line with Chinese state media, but still avoiding direct criticism of and confrontation with the Chinese government, i.e. by marking the publication of critical postings from online forums as not representing the standpoint of the editorial. By doing so, Europe Weekly provided a platform for critical voices without distancing itself from its Chinese partners. This strategy of avoiding turning against either China or Austria can, again, be regarded as transnational. In contrast to the People's Republic media, Europe Weekly did not fully reject Austrian and diverging overseas Chinese standpoints. 
Even when leaning towards the Chinese side, the Weekly tried to reconcile the allegedly opposing world views of Austria and China to a certain extent. In other words, Chinese patriotism was used as an emotional anchor but not as a marker of difference between overseas Chinese immigrants and Austria. This implicit strategy should be acknowledged as an attempt to retain at least some of the Weekly's transnational orientation, even if it sometimes seemed to be a walk on eggshells.

Finally, it should be kept in mind that the 2008 Tibetan crisis is an emotionally charged topic that offered little space for reconciliation. Findings in this specific context, therefore, are indicating a one-time strategy under very specific circumstances that should not be confused with the everyday situation of overseas Chinese journalism and, thus, should not be overrated. ${ }^{7}$

\section{Conclusion}

Overseas Chinese identity in Austria is drawing on the potential of four social spaces, each of them holding the promise of being a possible place of belonging. In general, Europe Weekly exposes its readers to news, information, and values from all four, bearing proof to the crucial role the media play in the formation of a Chinese transnational imagination. Reading the Weekly provides the opportunity of involvement in all four social spaces. Its content fosters an overseas Chinese identity that maintains native and traditional elements of Chineseness while simultaneously striving for the integration in the Austrian host society, as well as in local and transnational overseas Chinese communities. The newspaper enhances a pluralistic world view for its readers and, thus, provides a narrative of a hybrid Chinese identity that spans all four impact factors introduced in the theoretical model above. It displays different identity options, which, in the end, still accumulate into an image of the Austrian Chinese anchored in multiple cultural spaces.

Even in its coverage of the 2008 Tibetan unrest, when Europe Weekly promoted the rhetoric of a solidarity of the Chinese around the world with the Chinese nation state and emphasised a Chinese identity and anti-'Western' standpoint, it still avoided turning against the Austrian host society by counterbalancing critical articles towards the Western world with friendly ones about Austria. This means that, in its effort to remain open to specific Austrian Chinese perspectives, in some cases Europe Weekly deviated from nation state master narratives and replaced them with those of hybridity.

All this adds to the picture that Europe Weekly is meant to function as a platform for the Chinese community in Austria to reproduce and internalise its own multifari-

7 About the transnational reporting of overseas Chinese media in Austria during the Beijing Olympics, see Ritirc 2012. 
ousness. Most certainly, imaginations of being Chinese are never fully under the control of the Chinese nation state but, instead, belong to each and everyone who claims to be Chinese regardless of his or her affiliation. Overseas Chinese immigrants possess the power to participate in this struggle over identity. The ability of self-organisation-such as the semi-autonomous Europe Weekly-indicates that Chineseness varies from place to place, molded by national, local, and translocal circumstances. These new hybrid manifestations of identity, leading to 'many different Chinese identities, not one' (Ang 1998: 225), is not only enriching the cultural concept of Chineseness but also offers a chance to immigrants and host societies to handle their common future in an 'age of migration'. 


\section{LIST OF ABBREVIATIONS}

CCP

MA 17

OCAO

PRC
Chinese Communist Party

Municipal Department 17

Overseas Chinese Affairs Office

People's Republic of China 


\section{REFERENCES}

Ang, Ien. "Can one say no to Chineseness? Pushing the Limits of the Diaspora Paradigm." In Boundary 2, 23/2, 1998, pp. 223-242

Appadurai, Arjun. Modernity at Large: Cultural Dimensions of Globalization. Minneapolis: University of Minnesota Press, 1996

Barabantseva, Elena. "Trans-nationalising Chineseness: Overseas Chinese Policies of the PRC's Central Government.” In Asien, 96, 2005, pp. 7-28

Basch, Linda, Nina Glick Schiller, and Christina Blanc-Szanton. Nations Unbound: Transnational Projects, Post-colonial Predicaments, and De-terriorialized Nation-States. London and New York: Routledge, 1994

Berger, Peter and Thomas Luckmann. Die gesellschaftliche Konstruktion der Wirklichkeit: Eine Theorie der Wissenssoziologie. Frankfurt am Main: Fischer, 2009

Bhabha, Homi. The Location of Culture. London and New York: Routledge, 1994

Breton, Raymond. "Institutional Completeness of Ethnic Communities and the Personal Relations of Immigrants.” In American Journal of Sociology, 70/2, 1964, pp. 193-205

Brukaber, Rogers. "The Return of Assimilation? Changing Perspectives on Immigration and its Sequels in France, Germany, and the United States." In Ethnic and Racial Studies, 24/4, 2010, pp. 531-548

Bruner, Jerome. Making Stories: Law, Literature, Life. Cambridge: Harvard University Press, 2003

Chen, Wenhong. "The Impact of Internet Use on Transnational Entrepreneurship - The Case of Chinese Immigrants to Canada." In New Technologies in Global Societies, edited by Pui-Lam Law, Leopoldina Fortunati, and Shanhua Yang. New Jersey: World Scientific, 2006, pp. 197220

Christiansen, Flemming. Chinatown, Europe: An Exploration of Overseas Chinese Identity in the 1990s. London: Routledge Curzon, 2003

Cornell, Stephen and Douglas Hartmann. "Ethnizität und Rasse: Ein konstruktivistischer Ansatz." In Ethnowissen. Soziologische Beiträge zu ethnischer Differenzierung und Migration, edited by Marion Müller and Darius Zifonun. Wiesbaden: VS Verlag für Sozialwissenschaften, 2010, pp. 61-98

Die Presse. "Mit Tränengas gegen Tibets Mönche.” 13 March 2008, http://diepresse.com/home/politik/aussenpolitik/369396/China_Mit-Traenengas-gegen-TibetsMonche, accessed December 2015

Die Presse. "Mehrere Tote bei Protesten gegen China." 14 March 2008, http://diepresse.com/home/politik/aussenpolitik/369793/Tibet_Mehrere-Tote-bei-Protestengegen-China, accessed December 2015

Die Presse. "Vor China in die Knie gegangen?" 21 March 2008, http://diepresse.com/home/meinung/kommentare/371554/Meinung_Vor-China-in-die-Kniegegangen? parentid=186086\&showMask=1, accessed December 2015

Die Presse. "Tumulte bei olympischen Fackellauf." 7 April 2008, diepresse.com/home/politik/aussenpolitik/374939/Paris_Tumulte-bei-olympischem-Fackellauf, accessed December 2008

Ding, Sheng. "Digital Diaspora and National Image Building: A New Perspective on Chinese Diaspora Study in the Age of China's Rise." In Pacific Affairs, 80/4, Special Forum: East Timor's Truth Commission, 2007, pp. 627-648 
Esser, Hartmut. “Ethnische Kolonien: 'Binnenintegration' oder gesellschaftliche Isolation?” In Segregation und Integration: Die Situation von Arbeitsmigranten im Aufnahmeland, edited by Jürgen Hoffmeyer-Zlotnik. Mannheim: Forschung Raum und Gesellschaft, 1986, pp. 106-117

Europe Weekly. "Xīzàng liánrì bàofā dàguīmó kàngyì huódòng bìng dǎozhì sāoluàn” 西藏连日爆 发大规模抗议活动并导致骚乱 [Large Scale Protest and Riots in Lhasa for Several Days]. 17 March 2008, p. 1

Europe Weekly. "Zhōngguó zhù àodìlì dàshǐ qiănzé chōngjī shǐguăn shìjiàn” 中国驻奥地利大使 谴责冲击使馆事件 [Chinese Ambassador in Austria Condems Attack on Embassy]. 24 March 2008, p. 1

Europe Weekly. “Táiwān tiānkōng yòu xiàn lánsè” 台湾天空又见蓝色 [Taiwanese Sky Blue Again]. 24 March 2008, p. 1

Europe Weekly. "Wēixiào de zhōngguó” 微笑的中国 [China's Smile]. 31 March 2008, p. 1

Europe Weekly. “Zhōngguó zhù àodìlì dàshǐguăn jǔxíng bàogàohuì” 中国驻奥地利大使馆举行报 告会 [Chinese Embassy in Austria Holds Public Lecture]. 31 March 2008, p. 4

Europe Weekly. “1959 nián 3 yuè 10 rì xīzàng pànluàn zhēnxiàng” 1959 年 3 月 10 日西藏叛乱真 [The Truth About the Armed Rebellion in Tibet on March 3, 1959]. 7 April 2008, p. 15

Europe Weekly. “Zhōngguó xīzàng zhèngcè de mángdiăn” 中国西藏政策的盲点 [Blind Spots in China's Tibet Policy]. 7 April 2008, p. 18

Europe Weekly. “Xīfāng fãnhuá shìli wèihé gǔdòng zàngdú nàoshì” 西方反华势力为何鼓动藏独 闹事 [Why Anti-Chinese Forces in the West Incite Tibetan Independence Movement to Cause Trouble]. 21 April 2008, p. 4

Europe Weekly. “Yīngguó shǒuxiàng bùlăng jiàng cānjiā běijīng àoyùnhuì" 英国首相布朗将参加 北京奥运会 [British Prime Minister Gordon Brown Will Take Part in Beijing Olympics]. 28 April 2008, p. 4

Europe Weekly. “Lǐzhì shì xíngdòng de zhǔnzé” 理智是行动的准则 [Reason Is the Criterion for Action]. 28 April 2008, p. 6

Faßmann, Heinz. 2. Österreichischer Migrations- und Integrationsbericht 2001-2006. Vienna: Vienna University Press, 2007

Gergen, Kenneth J. and Mary Gergen. Einführung in den sozialen Konstruktionismus. Heidelberg: Carl-Auer Verlag, 2009

Hall, Stuart. "Wer braucht 'Identität'?” In Stuart Hall: Ideologie, Identität, Repräsentation. Ausgewählte Schriften 4, edited by Juha Koivisto and Andreas Merkens. Hamburg: Argument Verlag, 2004, pp. 167-187

Harrell, Stevan. Cultural Encounters on China's Ethnic Frontiers. Seattle and London: University of Washington Press, 1995

Hsu, Francis and Hendrick Serri. The Overseas Chinese: Ethnicity in National Context. Lanham: University Press of America, 1998

Kaminski, Gerd. Von Österreichern und anderen Chinesen. Wien: Löcker, 2011

Kissau, Kathrin. "Das Integrationspotential des Internet für Migranten.” Ph.D. diss., Münster University, 2008

Kwok, Kim. "Das Reich der Mitte auf der ganzen Welt.” Homepage Integration Fund, 2008, http://www.integrationsfonds.at/wissen/integration_im_fokus/integration_im_fokus_ausgabe_ 32008/international/das_reich_der_mitte_auf_der_ganzen_welt/, accessed January 2011

Li, Minghuan. 'We need two Worlds': Chinese Immigrant Associations in a Western Society. Amsterdam: Amsterdam University Press, 1999

Liu, Hong. "Old Linkages, New Networks: The Globalization of Overseas Chinese Voluntary Associations and its Implications.” In The China Quarterly, 155, 1998, pp. 582-609 
Manager Magazin. "Die fünfte Kolonne Pekings.” 3 April 2012, http://www.managermagazin.de/magazin/artikel/a-825249.html, accessed December 2015

Mayring, Philipp. Qualitative Inhaltsanalyse: Grundlagen und Techniken. Weinheim: Beltz, 2000 Morawska, Ewa. "Exploring Diversity in Immigrant Assimilation and Transnationalism: Poles, and Russian Jews in Philadelphia.” In International Migration Review, 28/4, 2004, pp. 1372 1412

Mosleh, Fariba. "Wien - Chinatown (In-) Visible Eine stadtethnologische Bestandsaufnahme zur Verortung der Chinesischen Community in Wien, Vienna." M.A. thesis, Vienna University, 2012

Nonini, Donald and Ong Aihwa. "Chinese Transnationalism as Alternative Modernity." In Ungrounded Empires: The Cultural Politics of Modern Chinese Transnationalism, edited by Donald Nonini and Aihwa Ong. London and New York: Routledge, 1997, pp. 3-33

Nyiri, Pal. "Chinese in Hungary and their Significant Others: A Multi-Sited Approach to Transnational Practice and Discourse." In Identities: Global Studies in Culture and Power, 9/1, 2002, pp. 69-82

Nyiri, Pal. Chinese in Eastern Europe and Russia: A Middleman Minority in a Transnational Era. London and New York: Routledge, 2007

Oswald, Ingrid. Migrationssoziologie. Konstanz: UTB, 2007

People’s Daily. “Shìshí bùróng niǔqū gōngdào zìzai rénxīn” 事实不容扭曲 公道自在人心 [Facts Should Not Be Distorted, A Sense of Justice Is Common to All People]. 24 March 2008, http://cpc.people.com.cn/GB/64093/64099/7033531.html, accessed December 2015

People's Daily. “Lāsà ' $3 \cdot 14$ ' dăzá qiăng shāo shìjiàn zhēnxiàng” 拉萨 “ $3 \cdot 14$ ” 打砸抢烧事件 真相 [Facts About the '3-14' Beating, Destruction of Property, Looting and Arson in Lhasa]. 21 March 2008. http://politics.people.com.cn/GB/1026/7031403.html, accessed December 2015

People's Daily. “Kànqīng suǒwèi “měimiào shénshèng de zhìdù”” 看清所谓”美妙、神圣的制度” [See Clearly the So-called 'Beautiful, Sacred System']. 6 April 2008, http://cpc.people.com.cn/GB/64093/64387/7084379.html, accessed December 2015

People's Daily. “Wúwèi nŭshēng jīn jīng yòng shēngmìng băowèi àoyùn huǒjù” 无畏女生金晶用 生命保卫奥运火炬 [Fearless Girl Jīn Jing Protects the Olympic Flame with Her Life]. 9 April 2008, http://world.people.com.cn/GB/1032/7096227.html, accessed December 2015

Pieke, Frank, Pál Nyíri, Mette Thun $\varnothing$, and Antonella Ceccagno. Transnational Chinese. Stanford: Stanford University Press, 2004

Phinney, Jean and Anthony Ong. "Conceptualization and Measurement of Ethnic Identity: Current Status and Future Directions.” In Journal of Counseling Psychology, 54/3, 2007, pp. 271-281

Pries, Ludger. Die Transnationalisierung der sozialen Welt. Frankfurt am Main: Suhrkamp, 2008

Ritirc, Julia. "Our Olympic Games? Transnational Chinese Overseas Identity and the Beijing Olympic Games 2008.” In Vienna Journal of East Asian Studies, 3, 2012, pp. 139-164

Sarup, Madan. "Home and Identity." In Travelers' Tales: Narratives of Home and Displacement, edited by George Robertson, Jon Bird, Barry Curtis, Melinda Mash, Tim Putnam, and Lisa Tickner. London and New York: Routledge, 1994, pp. 93-104

Schäfer, Carsten and Fariba Mosleh. "Chinas Ankunft in Österreich.” In Vienna Chinatown (In)Visible: Eine Reise durch das chinesische Wien, edited by Fariba Mosleh. Vienna: Praesens, 2014, pp. 30-41

Schäfer, Carsten. "Von Marginalisierung, Mafia und Medienklischees." In Vienna Chinatown (In)Visible: Eine Reise durch das chinesische Wien, edited by Fariba Mosleh. Vienna: Praesens, 2014, pp. 52-63 
Schäfer, Carsten. "Identity Construction and Patterns of Incorporation of Overseas Chinese in Austria. The Case of outuo.net." Ph.D. diss. University of Vienna, forthcoming

Sen, Amartya. Die Identitätsfalle: Warum es keinen Krieg der Kulturen gibt. Munich: C. H. Beck, 2007

Shi, Yu. "Identity Construction of the Chinese Diaspora, Ethnic Media Use, Community Formation, and the Possibility of Social Activism." In Continuum, 19/1, 2010, pp. 55-72

Sun, Wanning. "Introduction: Transnationalism and a Global Diasporic Chinese Mediasphere." In Media and the Chinese Diaspora: Community, Communications and Commerce, edited by Sun Wanning. London and New York: Routledge, 2006, pp. 1-25

Tang, Lu. "Diaspora Television and Cultural Identity: A Case Study." 2004, http://citation. allacademic.com/meta/p_mla_apa_research_citation/1/1/3/2/4/pages113244/p113244-1.php, accessed February 2014

Telephone Book for Chinese in Austria 2012 (Àodilì huárén shāngyè diànhuàbáo 2012 niánbăn 奥 地利华人商业电话薄 2012 年版). Vienna: Nouvelles D’Europe, 2012

Thuno, Mette. "Reaching Out and Incorporating Chinese Overseas: The Trans-Territorial Scope of the PRC by the End of the 20th Century." In China Quarterly, 168, 2001, pp. 910-929

Treibel, Annette. Migration in modernen Gesellschaften: Soziale Folgen von Einwanderung und Gastarbeit. Weinheim: Beltz Juventa, 1990

Verhulst, Stefaan. "Diasporic and Transnational Communication: Technologies, Policies and Regulations." In The Public, 6/1, 1999, pp. 29-36

Wang, Gungwu. “Among Non-Chinese.” In Daedalus, 120/2, 1991, pp. 135-157

Wáng, Găn 王敢. “Cóng ‘Ōuzhōu liánhé zhōubào’ bàoxì kān bàozhǐ zhěnghé hé fāzhăn”从 《欧洲 联合周报》报系看报纸整合和发展 [Looking at the Newspaper’s Development and Integration From the Europe Weekly's Perspective]. 2007, http://news.xinhuanet.com/zgjx/200709/03/ content_6656348.htm, accessed July 2010

Weggel, Oskar. Das Auslandschinesentum: Wirtschaftsmotor und Inspsirationsquelle. Hamburg: Institut für Asienkunde, 1999

Wickberg, Edgar. "Global Chinese Migrants and Performing Chineseness." In Journal of Chinese Overseas, 3/2, 2007, pp. 177-193

http://www.hudong.com/wiki/ 欧洲联合周报, accessed July 2010

http://www.integrationsfonds.at/wien/, accessed February 2016

https://www.wien.gv.at/menschen/integration/, accessed February 2016 


\section{GLOSSARY}

\begin{tabular}{|c|c|c|}
\hline Běijīng & 北京 & $\begin{array}{l}\text { Capital of the People's Republic of } \\
\text { China }\end{array}$ \\
\hline Gānsù & 甘肃 & $\begin{array}{l}\text { Chinese province located in the } \\
\text { northwest of the country }\end{array}$ \\
\hline Guóji fănhuá shili & 国际反华势力 & Anti-Chinese international forces \\
\hline huáqiáo huárén & 华侨华人 & Overseas Chinese \\
\hline jiēkòu & 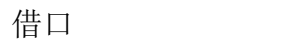 & excuse \\
\hline $\begin{array}{l}\text { Ōuzhōu Liánhé Zhōubào } \\
\text { Àodilì }\end{array}$ & 欧洲联合周报奥地利 & Europe Weekly \\
\hline Ōuzhōu Shíbào & 欧洲时报 & Europe Times \\
\hline Qīnghăi & 青海 & $\begin{array}{l}\text { Chinese province located in the } \\
\text { northwest of the country }\end{array}$ \\
\hline Rénmín Ribào & 人民日报 & $\begin{array}{l}\text { People's Daily; official newspaper of } \\
\text { the Chinese Communist Party }\end{array}$ \\
\hline Shànghăi & 上海 & $\begin{array}{l}\text { Major city located in the Yángzi 长 } \\
\text { 江 River Delta }\end{array}$ \\
\hline Sìchuān & 四川 & $\begin{array}{l}\text { Chinese province located in the } \\
\text { southwest of the country }\end{array}$ \\
\hline xijī & 袭击 & to attack \\
\hline Xīnmín Wănbào & 新民晚报 & Xīnmín Evening News \\
\hline
\end{tabular}

